\title{
TBO/LBO: An Effective Teaching And Learning System
}

Richard E. Coppage, (Email Coppage@Louisville.Edu), University Of Louisville Dr. George R. French, (Email Gfrench@Ius.Edu), Indiana University Southeast

\begin{abstract}
This article describes a teaching/learning style that incorporates teamwork and participative management, taken from the well-grounded system Management by Objectives (MBO), while assuring that the skills important to future career opportunities are included in the course objectives. The article begins with a description of the elements of the TBO/LBO process, followed by an identification of the main objectives, teaching learning strategies, and assessment methods. Next, the article discusses the lessons learned using $T B O / L B O$ and assesses the effectiveness of $T B O / L B O$ by reviewing the literature regarding Management By Objectives (MBO). The literature review revealed overwhelming support for the effectiveness of MBO. Finally, suggestions for future research are discussed.
\end{abstract}

\section{INTRODUCTION}

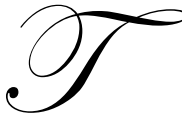

skills. Thus, ways to include these and other important topics throughout the business curriculum would be desirable

here has been increased emphasis on change in business education. Educators, recruiters, and even the graduates themselves find that recent graduates don't have the necessary skills required in today's business environment. Some of the deficiencies emphasized include communication, interpersonal and technology

Educators are constantly looking for more effective learning methodologies. The most appropriate learning strategies depend upon many variables, including the abilities of the instructors and students. This article describes a teaching/learning style that incorporates teamwork and participative management in the classroom while assuring that the skills important to future career opportunities are included in the course objectives. The learning style relies upon two vital components: 1) teaching efforts that incorporate specific classroom objectives - teaching by objectives (TBO), and 2) student learning that focuses on important classroom objectives - learning by objectives (LBO). The structure of the course is based on mutually agreed upon classroom objectives that are decided through a collaborative effort between the students and their instructor.

TBO/LBO is very similar to management by objectives (MBO), which has been found to be an effective management system (Rogers \& Hunter, 1991; Dolan, 2003; Marche, 2003; McNory, 2003 and Others). Student participation in setting both the objectives and the structure of a course motivates them to achieve goals that are important to them. The students have a greater understanding of course objectives and agree with the course requirements. Cooperative efforts between the teacher and students create an environment that motivates students to learn. The instructor and students' efforts are focused to achieve course outcomes that are considered essential by all parties involved. The ideal result is a single team comprised of the instructor and students striving to accomplish the objectives.

\section{ELEMENTS OF THE TBO/LBO PROCESS}

At the beginning of the semester, objectives are formulated by the students and the instructor. The first homework assignment announced at the beginning of the semester requires students to develop objectives for the course. Prior to the 
semester, the instructor should develop preliminary objectives for the course. Based upon prior experience, the instructor will typically have a more exhaustive list than the students. This listing would also include any objectives that are required to be covered in the course. At a subsequent class meeting, the instructor solicits objectives from the students. The instructor and the class should clarify the suggested objectives and list them on the blackboard for discussion. After the students have exhausted their lists, the instructor adds his/her objectives that have not been specified by the students. The resulting list represents plausible course objectives for the upcoming semester.

The instructor and class determine which objectives are appropriate for the particular course. During this process, the importance of each objective is discussed. An objective is acceptable only if it is perceived as instrumental to the students' development. It should be obvious by now that the instructor has significant influence regarding the objectives ultimately chosen. However, a vital ingredient required to make the technique effective is the students' agreement and understanding of the importance of each objective.

The discussion now turns to the most effective methods that may be utilized to accomplish the chosen objectives. This step involves determining specific tasks for the instructor and students that will accomplish each objective. The students and instructor develop the course requirements as a team with a specific understanding of how their actions will result in the accomplishment of the mutually agreed upon objectives. The students also are responsible for collaborating in the development of performance measurements, which will be used to evaluate themselves. The instructor will teach and the students will learn using the mutually agreed upon objectives. The overall objective is to utilize teamwork and participative management to increase the productivity and satisfaction of those involved.

\section{IDENTIFYING MAIN OBJECTIVES}

An accounting course will be used to illustrate the process. In prior intermediate accounting courses, five main objectives were routinely identified by students as important to their success. These objectives and the factors making each important are presented in Exhibit A. The five main objectives have been described as follows:

Increased knowledge of subject matter. Students recognized that an understanding of certain material is advantageous to obtain a job and to advance in their career. The necessity of a thorough understanding of financial accounting to pass the professional accounting exams was also expressed.

Enhancement of critical thinking and problem-solving skills. These skills were considered essential when approaching new situations that arise in the workplace. The need to develop logical and intuitive approaches in the analysis of complex business problems is essential throughout the accountant's career. Additionally, highly developed problem-solving skills are necessary for success on the professional examinations.

Exhibit A: Course Objectives And Reasons For Importance To Student

\begin{tabular}{|c|c|c|}
\hline Objective & & Importance of Objective \\
\hline Increase knowledge of course subjects & $\begin{array}{l} \\
\end{array}$ & $\begin{array}{l}\text { To obtain a job and advance a professional career } \\
\text { To pass professional examinations }\end{array}$ \\
\hline Enhance critical thinking and problem-solving skills & $\begin{array}{l}\square \\
\square\end{array}$ & $\begin{array}{l}\text { To address new problems as they arise on the job } \\
\text { Necessary for success on professional examinations }\end{array}$ \\
\hline Develop effective oral and written communication skills & $\begin{array}{l}\square \\
\square\end{array}$ & $\begin{array}{l}\text { Necessary for teamwork with colleagues and clients } \\
\text { Beneficial to service contributions personal activities }\end{array}$ \\
\hline Enhance computer application skills & $\square$ & Completion of job assignments \\
\hline $\begin{array}{l}\text { Acceptance of responsibility for professional and personal } \\
\text { activities }\end{array}$ & $\begin{array}{l} \\
\end{array}$ & $\begin{array}{l}\text { Fulfillment of professional obligations } \\
\text { Fulfillment of personal obligations }\end{array}$ \\
\hline
\end{tabular}


Effective Communication Skills. This objective was most important to the students. Communication skills are essential to both the personal and professional success of the students. Communication skills are frequently cited by professionals as key determinants of their success.

Acceptance of personal responsibility. The most effective students and professionals are capable of balancing and achieving personal, educational, and career goals. Sacrificing any of these goals may lead to short-term results at the expense of long-term achievement of goals and satisfaction.

\section{ESTABLISHING EFFECTIVE TEACHING/LEARNING STRATEGIES \& ASSESSMENT METHODS}

After establishing the main objectives of the course, the instructor must ask the question, "What are the most appropriate teaching, learning, and assessment methods to accomplish our objectives?" Discussion that follows typically focuses on traditional teaching methods. More innovative learning strategies often require thorough discussion and some compromise by both students and their instructor. The overriding goal is to develop a consensus among the classroom participants regarding the most appropriate teaching methods to accomplish the established objectives for the course. The focus of these discussions should be on the identification of effective strategies that maximize student learning and most effectively utilize available educational resources. The students must also realize their responsibilities for assisting the instructor in the acquisition of necessary resources. Additionally, the students and instructor will be responsible for developing effective assessment tools that reflect the level of student learning and will be typically administered by the instructor.

Exhibit B displays teaching, learning, and assessment methods that were developed through a consensus among students and the instructor in previous intermediate accounting classes. These methods were expected by classroom participants to represent the best practices to accomplish the objectives previously identified for successful completion of the course. The following discussions elaborate on the methods chosen by the class to accomplish five objectives discussed previously.

Objective 1 - Increase knowledge of the subject matter: It was decided by the class that the instructor would discuss solutions to homework and lecture on new material. The students agreed to read the chapters and make a valid attempt to complete the homework assignments prior to coverage in class. It was agreed that exams and quizzes would be used to assess students' progress in this area. Using this methodology is also consistent with the necessary preparation that students will undertake when readying themselves for professional examinations.

Objective 2 - Enhance critical thinking and problem solving abilities: As previously discussed, valid student attempts to complete required homework prior to class was considered essential to the development of problem solving skills. It was also agreed that during class, the instructor would ask complex questions requiring utilization of students' critical thinking abilities. As an individual student verbally responded to the class question, other students were expected to participate by silently analyzing the problem and developing their own solution. If any students were disruptive during the exercise (e.g., talking in class, etc.), they would be required to answer additional questions from the instructor on demand. Homework assignments, quizzes, and examinations were used in the final evaluation of student progress.

Objective 3 - Effective Communication skills: Both written and oral communication skills were considered essential to the successful career of a professional. Oral communication was required in class when querying students for their solutions to class assignments and additional questions from the instructor. Written communication skills were developed by students through completion of required writing assignments, such as memos to clients explaining appropriate accounting methods, throughout the semester. Additionally, essay questions requiring organizational and writing abilities were also administered on the examinations. The instructor will find that when using the TBO/LBO teaching strategies, significantly greater interpersonal communication skills will be required in the delivery of the course.

Objective 4 - Enhancing Computer Application skills: Computer applications requiring the use of electronic spreadsheets and using accounting data were required throughout the semester to enhance the students' technical skills. The instructor provided timely feedback on the computerized assignments throughout the grading period. 
Objective 5 - Accepting Personal Responsibility for Assignments: The acceptance of personal responsibilities by both the students and their instructor was agreed upon in the initial stages of the course. The instructor was expected to clearly communicate due dates for homework and other assignments. Feedback from graded assignments was expected to be prompt and sufficiently detailed to provide opportunities for improvement. Attendance by the students was their personal responsibility and was not directly evaluated. Students were expected to meet deadlines for their assignments and late assignments incurred a penalty.

\section{Exhibit B: Teaching/Learning Strategies \& Assessment Methods}

\begin{tabular}{|l|ll|}
\hline \multicolumn{1}{|c|}{ Course Objectives } & \multicolumn{1}{c|}{ Teaching/Learning Strategy\& Assessment Methods } \\
\hline Increased knowledge of course subjects & $\square$ & $\begin{array}{l}\text { Read course material, completion of homework assignments, class } \\
\text { lecture } \\
\text { Class quizzes and examinations }\end{array}$ \\
\hline $\begin{array}{l}\text { Enhanced critical thinking \& problem- } \\
\text { solving skills }\end{array}$ & $\square$ & $\begin{array}{l}\text { Homework discussion, developing solutions to complex problems, } \\
\text { class participation, completion of homework assignments } \\
\text { Random grading of homework assignments, class quizzes and } \\
\text { examinations }\end{array}$ \\
\hline $\begin{array}{l}\text { Develop effective oral and written } \\
\text { communication skills }\end{array}$ & $\square$ & $\begin{array}{l}\text { Class queries and responses, library reports, class participation } \\
\text { Grading of library reports, grading of class participation }\end{array}$ \\
\hline Enhance computer application skills & $\square$ & $\begin{array}{l}\text { Computer spreadsheet projects } \\
\text { Grade computer projects }\end{array}$ \\
\hline $\begin{array}{l}\text { Acceptance of responsibility for professional } \\
\text { and personal activities }\end{array}$ & $\square$ & $\begin{array}{l}\text { Establish and meet due dates for class assignments, expect class } \\
\text { attendance, completion of class readings and homework assignments } \\
\text { prior to class coverage } \\
\text { Evaluate compliance with due dates, student self-evaluation of level } \\
\text { of course preparations }\end{array}$ \\
\hline
\end{tabular}

\section{LESSONS LEARNED USING TBO/LBO}

Based on student comments, we perceive that the students enthusiastically embraced the learning experience when the TBO/LBO approach is utilized. Students appreciate being asked for their opinion and have commented that the elaboration of course objectives solidified their understanding of the many benefits they received during their learning experience. Classes have never attempted to unreasonably limit the rigor of the course. The resulting objectives and structure of the course have always resembled a typical course, with emphasis placed on knowledge acquisition, enhancing problem-solving skills, improving communication and technical skills, and accepting personal responsibility. The students are emphasizing the same skills they know will benefit them after graduation. Interestingly, the student empowerment approach is consistent with the employee empowerment concepts that are benefiting the business environment that students are studying. Through the instructor's empowerment of the students and their subsequent successes early in their careers, the students will be able to more effectively empower their own subordinates.

\section{ASSESSING THE EFFECTIVENESS OF TBO/LBO}

While there has been little research directly related to assessing the effectiveness of TBO/LBO with the exception of anecdotal evidence, there has been extensive research on management-by-objectives (MBO), which is the recognized system that is the basis of TBO/LBO. A literature review reveals that there is overwhelming evidence that $\mathrm{MBO}$ has been highly effective (Guzzo et al., 1985; Rodgers and Hunter, 1991; Woodman \& Wayne, 1985). The MBO process involves three main components: goal setting, participative decision making and feedback.

In a classroom setting the goal setting takes place on the first or second class meeting as the instructor, along with the students, determine the goals of the course. Once the objectives of the course are agreed upon they must be 
continuously monitored and revised only when absolutely necessary, while keeping everyone's attention on the accomplishment of the goals. Participative decision making takes place throughout the term of the course starting with the setting of the goals and ending with the evaluation of the instructor, course, and students. Rather, than top down leadership, everyone participates in the decision making process allowing for greater cooperation, better understanding and thus greater productivity. The course is continuously reevaluated and redesigned to reflect the needs of the students and the accounting profession, which is also consistent with AACSB requirements to systematically assess the relevance of the curriculum. Objective feedback in a course setting would include periodic evaluation of students and instructor to encourage continuing participation toward accomplishing the agreed upon goals.

Numerous literature review studies regarding the effectiveness of $\mathrm{MBO}$ have been conducted (Dolan, 2003; Marche, 2003; McNary, 2003; Rodgers \& Hunter, 1991). Rodgers \& Hunter (1991) reviewed 70 prior studies and found that 68 out of 70 showed productivity gains. Gibson et al (2003) confirmed that MBO is not a fad, but a recognized management system. Other studies have recognized the benefits of MBO when managing remote workers, which is very similar to the teacher/student relationship. Konradt, V. et al (2003) conducted a study that concluded "adequate training in MBO is strongly recommended..." for managing remote workers. Use of MBO "provides successful management techniques for remote work, reducing stress and increasing job satisfaction."

\section{SUGGESTIONS FOR FUTURE RESEARCH}

While this article inferred effectiveness of TBO/LBO by association with $\mathrm{MBO}$, more can be done to assess the strengths and weaknesses of TBO/LBO. A comparison of two courses, both similar with the exception of using TBO/LBO in one course, would provide greater insight into using a system similar to $\mathrm{MBO}$ in a classroom setting. A review of the MBO studies provides an endless list of specific variables that can be explored elated specifically to TBO/LBO.

Improvements in the TBO/LBO process is another area of future research. The most appropriate way to approach goal setting; participative decision-making and feedback in a classroom setting should be constantly questioned.

\section{CONCLUSIONS}

The TBO/LBO educational technique discussed in this article may be used in any course. All of the aforementioned techniques may be employed, although the instructor may find it effective to use only part of them. Once the objectives, teaching/learning strategies, and assessment methods have been determined, based on a measure of usefulness to the students' futures, a higher level of self-directed student learning can occur and the teacher assumes the primary role of managing the process. Because students realize the potential benefits of achieving each objective, they will assume personal responsibility for achieving the course objectives. Since students share responsibility for the success of the course, they exhibit a higher level of motivation for achieving the course objectives. The instructor is perceived as an important facilitator of the classroom processes that must be undertaken to achieve these objectives. The end result is a more rewarding learning experience for both the students and the instructor.

\section{REFERENCES}

1. Dolan, S.L. (March, 2003). Understanding and managing chaos in organizations. Journal of Management, 20(1), 23-36.

2. Gibson, J.W. et al. (2003). Management Fads: Here Yesterday, Gone Today? SAM Advanced Management Journal, Autumn, 12-17.

3. Guzzo, R. A., \& Bondy, J. S. (1983). A guide to worker productivity experiments in the United States 1976-81. New York: Pergamon Press.

4. Konradt, V. et al. (2003). Quality of Management by Objectives, Task-Related Stressors, and Non-Task-Related Stressors as Predictors of Stress and Job Satisfaction Among Teleworkers. European Journal of Work and Organizational Psychology, 12, (1), 61-79.

5. McNary, L. (2003). The term "win-win" in conflict management: A classic case of misuse and overuse. Journal of Business Communication, 40(2), 144-60. 
6. Marche, S. (2003, March). The expansion of management knowledge: Carriers, flows, and sources. Canadian Journal of Administrative Sciences, 20(1), 89-91.

7. Rodgers, R., \& Hunter, J. E. (1991). Impact of management by objectives on organizational productivity. Journal of Applied Psychology, 76(2), 322-337.

8. Woodman, R. W. \& Wayne, S. J. (1985). An investigation of positive-findings bias in evaluation of organization development interventions. Academy of Management Journal, 28, 889-913.

\section{Notes}

